\title{
Research note \\ First report of Syphacia vanderbrueli Bernard, 1961 (Oxyuridae) from Micromys minutus in Poland
}

\author{
G. ZALEŚNY, J. HILDEBRAND, A. PEREC-MATYSIAK, A. OKULEWICZ
}

\begin{abstract}
Department of Parasitology, Institute of Genetics and Microbiology, University of Wroclaw, Przybyszewskiego 63, 51-148 Wroclaw; E-mail: zalesny@microb.uni.wroc.pl
\end{abstract}

\section{Summary}

During the parasitological examination of wild rodents from Wroclaw vicinity 11 female nematodes were isolated from the harvest mouse (Micromys minutus). The helminths were determined as Syphacia vanderbrueli. This is the first report of this parasite in Poland. Complete descriptions of the female individuals are given.

Key words: Syphacia vanderbrueli; rodents; Poland

\section{Introduction}

Nematodes belonging to the genus Syphacia are typical parasites colonizing large and small intestine of wild rodents. According to Fauna Europaea data, 12 species were described so far in Europe, however in Poland only 7 of them were confirmed: $S$. agraria, $S$. frederici, $S$. nigeriana, $S$. stroma, S. petrusewiczi from Lower Silesia (Hildebrand et al., 2004; Popiolek et al., 2004); S. frederici, S. montana, $S$. stroma from Warszawa area (Guerero, 1979) and $S$. petrusewiczi from the Mazury Lake District (Bernard, 1966; Behnke, 2001). S. obvelata was recorded from different re-gions of Poland (Pojmańska, 1998) but in accordance with papers by Quentin (1971) and Hugot (1988), the asserta-tion of $S$. obvelata in other hosts than Mus musculus still needs a revision.

\section{Material and Methods}

During the parasitological study of wild rodents from Wroclaw vicinity one individual of harvest mouse (Micromys minutus) was obtained and subjected to standard helminthological section. As a result of the section 11 female nematodes belonging to the genus Syphacia were found in caecum. Material was maintained in $70 \%$ ethanol, fixed and cleared for examination with lactophenol.

\section{Results and Discussion}

According to Bernard (1966a), Quentin (1971), Tenora and Mészaros (1975), Ryzhikov et al. (1979) and Genov (1984) specimens were determined as Syphacia vanderbrueli, as well as the harvest mouse (M. minutus) is confirmed to be the specific host for this oxyurid so far. Simultaneously this is the first record of this parasite in Poland. The adult female parasites were examined to determine species composition with regard to their morphologic and morphometric characteristics, previously described by Tenora and Mészaros (1975). Length of the female body and tail size, in comparison with another species of genus Syphacia described in rodents, are relatively bigger. Head end is elongated laterally and similar to structure of $S$. frederici head. Lateral alae well developed intruding into cephalic vesicle and extending to tail end. Anterior part of inner surface of esophagus serrated (Fig. 1A, B). The measurements expressed in milimeters (minimum-maximum) of the most representative structures of $S$. vanderbrueli are

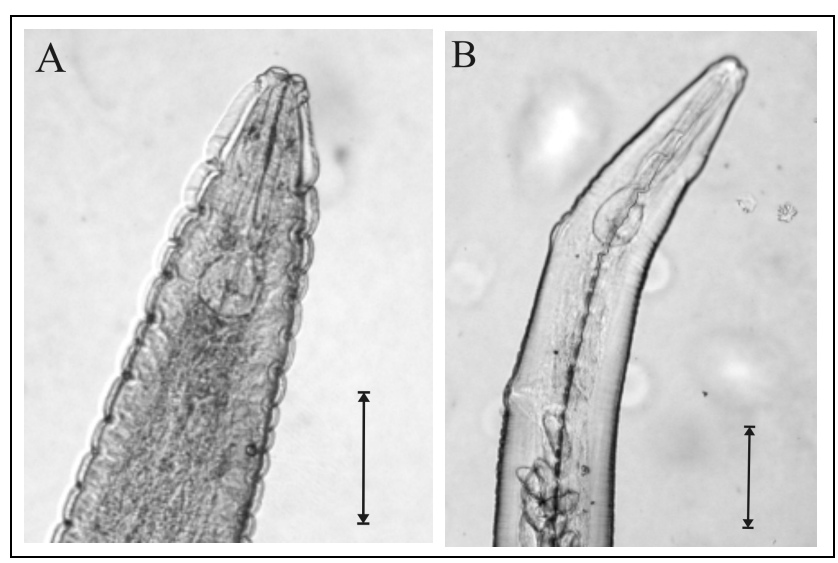

Fig. 1. Syphacia vanderbrueli (Bernard, 1966) from Poland, (scale bar $=0,2 \mathrm{~mm}$ ),

$\mathrm{A}$ - anterior part of female, dorsal; B - anterior part of female, lateral 
Table 1. Comparison of morphometric data (expressed in mm) of Syphacia vanderbrueli (Bernard, 1961) from Micromys minutus in Europe

\begin{tabular}{lccccc}
\hline & Bernard, 1966a & $\begin{array}{c}\text { Tenora and } \\
\text { Mészaros, 1975 }\end{array}$ & Genov, 1984 & Ryzhikov, 1979 & $\begin{array}{c}\text { Material from } \\
\text { Poland }\end{array}$ \\
\hline $\begin{array}{l}\text { Lenght of body } \\
\text { Max widith of body }\end{array}$ & $4.41-6.41$ & $4.80-5.80$ & $4.12-5.78$ & $4.51-5.62$ & $4.57-5.46$ \\
$\begin{array}{l}\text { Lenght of } \\
\text { esophagus }\end{array}$ & $0.228-0.312$ & $0.21-0.29$ & $0.212-0.331$ & $0.22-0.28$ & $0.28-0.39$ \\
Nerve ring & $-0.32-0.39$ & $0.30-0.37$ & $0.335-0.391$ & $0.32-0.35$ & $0.38-0.49$ \\
$\begin{array}{l}\text { Excretory pore } \\
\text { from anterior }\end{array}$ & $0.39-0.61$ & $0.15-0.16$ & $0.138-0.157$ & $0.14-0.19$ & $0.13-0.14$ \\
extremity & & $0.43-0.55$ & $0.146-0.544$ & $0.41-0.65$ & $0.43-0.48$ \\
Vulva from anterior & $0.76-1.22$ & $0.87-1.04$ & $0.732-0.970$ & $0.78-0.95$ & $0.74-0.92$ \\
extremity & $0.83-0.95$ & $0.64-0.97$ & $0.74-1.02$ & $0.8-1.0$ & $0.62-1.06$ \\
Lenght of tail & $0.082-0.103 \times$ & $0.112-0.123 \times$ & $0.107-0.124 \times$ & $0.100-0.123 \times$ & $0.123-0.133 \times$ \\
Eggs & $0.026-0.041$ & $0.031-0.041$ & $0.035-0.047$ & $0.031-0.041$ & $0.031-0.051$ \\
\hline
\end{tabular}

given in Table 1. Our results were compared with available data described $S$. vanderbrueli in details (Tab. 1). Based on the comparison of the metrical data from Belgium (Bernard, 1966a), Bulgaria (Genov, 1984), Hungary (Tenora \& Mészaros, 1975) and Ukraine (Ryzhikov et al., 1979) material from Poland corresponds to the previous descriptions of this species. So far Syphacia vanderbrueli has been recorded in eight countries in Europe. Faunistic researches carried out in our country contribute to complete the list of European species.

\section{Reference}

BERNARD, J. (1966): Nematodes de micromammiferes recoltes en Europe Centrale. Arch. Inst. Pasteur, Tunis, 4: $609-632$

BERnARD, J. (1966a): Les Syphacia spp. parasites des rongeurs de la faune belge avec description d'une nouvellee espece: Syphacia vanderbrueli, parasite de Micromys minutus. Pall. Bull. rech. agron. Gembloux, 3: 345 - 358

Behnke, J. M., BArnard, C. J., Bajer, A., Bray, D., Dinmore, J., Frake, K., OSMOND, J., RACE, T., Sinski, E. (2001): Variation in the helminth community structure in bank voles (Clethrionomys glareolus) from three comparable localities in the Mazury Lake District region of Poland. Parasitology, 123: 389 - 400

GENOV, T. (1984): Helminths of insectivores and rodents in Bulgaria. Publishing House of the Bulgarian Academy of Sciences, Sofia [In Bulgarian]

GUERERO, R. (1979): The structure of the endoparasite hel- in an urban gradient. $\mathrm{PhD}$ thesis: Institute of Parasitolgy, Polish Academy of Science

Hildebrand, J., PopioleK, M., OKulewicz, A., ZALEŚNY, G. (2004): Helminthfauna of mice of Apodemus genus from Wrocław area. Wiad. Parazytol., 50: 623 - 628 [In Polish]

Hugot, J. P. (1988): Les nematodes Syphaciinae, parasites de Rongeurs et de Lagomorphes. Mem. Mus. Nat. Hist. Natl. A Zool., t. 141, pp. 148

PoJMAŃSKA, T. (1998): Catalogue of Parasite Fauna of Poland. Part V. Parasites of Mammals Vol. 1 - Insectivora, Chiroptera Lagomorpha and Rodentia. Endoparasites. Polish Parasitological Society. Warszawa [In Polish] PopioŁeK, M., Hildebrand, J., KARPińsKA, M., IndYK, F., PAWŁOWSKA-INDYK, A. (2004): Nematodes of rodents from Jelenia Góra district. Wiad. Parazytol., 50: 629 - 635 [In Polish]

Quentin, J. C. (1971): Morphologie comparée des structures céphaliques et génitales des oxyures du genre Syphacia. Ann. Parasit., 46: $15-60$

Ryzhikov, K. M., Gvozdev, E. V., ToKobaev, M. M., Schaldybin, L. S., MacABeridze, G. V., MerkuscheVA, I. V., NADTOCHIJ, E. V., Chochlova, I. G., Sharpilo, L. D. (1979): Key to the helminth fauna of rodents in the U.S. S. R. Nematodes and Acanthocephales. Public House "Nauka", Moscow [In Russian]

TenorA, F., Mészaros, F. (1975): Nematodes of the genus Syphacia Seurat, 1916 (Nematoda) - parasites of rodents (Rodentia) in Czechoslovakia and Hungary. Acta Univ. Agric., 3: 537 - 354

http://www.faunaeur.org/ 